\title{
Peran Kearifan (Wisdom) terhadap Kecemasan menghadapi Kematian pada Lansia
}

\author{
The Role of Wisdom Towards Death Anxiety in The Elderly \\ Smita Dinakaramani ${ }^{1} \mathcal{E}$ Aisah Indati ${ }^{2}$ \\ 1,2Fakultas Psikologi Universitas Gadjah Mada
}

\begin{abstract}
The development of individuals ends with the last step of being an elderly. Throughout their journey, they accumulate experience which results in the wisdom. A wise elder is often described having a good judgement, empathy, and the ability to accept change in their life including the acceptance of death as just another phase of life. The aim of this study is to find out the role of wisdom towards death anxiety among the elderly. The hypothesis of this study is "Wisdom has an role towards death anxiety". This study uses an adaptation of the Death Anxiety Scale (DAS) and the Three-Dimensional Wisdom Scale (3D-WS) as measuring instruments. This study analyze 130 elderlies between 60 and 85 years old that don't stay in retirement homes. The data is analyzed using simple linear regression technique. The result of this study shows wisdom has a role towards elderly death anxiety by $14.3 \%$.
\end{abstract}

Keywords: death anxiety; elderly; wisdom

\begin{abstract}
Abstrak. Lansia merupakan tahapan terakhir dalam perkembangan manusia. Kearifan merupakan resolusi dari tugas perkembangan oleh lansia. Lansia yang arif dicirikan sebagai individu yang memiliki kemampuan penilaian yang baik, berempati dengan orang lain, dan menerima perubahan-perubahan dalam hidupnya termasuk menerima kematian. Penelitian ini bertujuan untuk mengetahui peran kearifan terhadap kecemasan menghadapi kematian pada lansia. Hipotesis dalam penelitian ini adalah kearifan memiliki peran terhadap kecemasan menghadapi kematian pada lansia. Subjek penelitian berjumlah 130 orang merupakan lansia dengan rentang usia 60 - 85 tahun yang tidak tinggal di panti wredha. Penelitian ini menggunakan alat ukur adaptasi dari Death Anxiety Scale (DAS) dan Three-Dimensional Wisdom Scale (3D-WS). Data dianalisis dengan teknik regresi linear sederhana. Hasil penelitian menunjukkan adanya peran kearifan terhadap kecemasan menghadapi kematian pada lansia sebesar $14.3 \%$.
\end{abstract}

Kata kunci: kearifan; kecemasan menghadapi kematian; lansia

Populasi lansia di Indonesia setiap Peningkatan usia harapan hidup di tahunnya meningkat seiring dengan Indonesia dapat dilihat dari data yang peningkatan usia harapan hidup. diambil pada tahun 2015, usia harapan

\footnotetext{
${ }^{1}$ Korespondensi mengenai artikel ini dapat melalui: smita.dinakaramani@mail.ugm.ac.id;

2indati_psy@ugm.ac.id
} 
hidup masyarakat Indonesia meningkat dari 68,6 tahun pada tahun 2004 menjadi 72 tahun pada tahun 2015. Data yang diambil oleh Badan Perencanaan Pembangunan Nasional juga memproyeksikan jumlah penduduk Indonesia pada tahun 2025 akan mencapai 273 juta jiwa dan hampir seperempatnya atau 62,4 juta jiwa tergolong lansia. Bahkan jumlah lansia pada tahun 2025 diperkirakan mencapai 120 jiwa (Kompas, 2016).

Peningkatan angka harapan hidup disebabkan oleh pesatnya perkembangan teknologi bidang kesehatan membuat permasalahan mengenai kesejahteraan hidup lansia menjadi semakin penting (Stephoe, Deaton, \& Stone, 2015). Selain kesejahteraan hidup, masyarakat juga perlu menyadari pentingnya mempertahankan kesehatan fisik maupun psikologis serta bagaimana lansia tersebut menjalani kehidupannya. Ketiga dimensi ini penting untuk dipertahankan karena merupakan landasan dasar lansia dalam mencapai successful aging (Liffiton, Horton, Baker, \& Weir, 2012).

Peningkatan harapan hidup di Indonesia tidak membuat Indonesia bebas dari permasalahan-permasalahan, terutama permasalahan yang dialami oleh lansia (Cao \& Rammohan, 2016). Permasalahan tersebut berupa permasalahan ekonomi dan permasalahan psikologis.

Permasalahan psikologis yang terjadi di masa lansia adalah permasalahan yang berkaitan dengan tugas-tugas perkembangan lansia. Menurut Havinghurst, tugas perkembangan yang diemban lansia berupa penyesuaian diri terhadap penurunan-penurunan yang terjadi. Penurunan tersebut baik berupa fisik maupun psikologis. Selain itu, lansia juga memiliki tugas untuk menyesuaikan diri dengan datangnya kematian (Hurlock, 1980).
Sejak awal kehidupan manusia, kematian merupakan suatu fakta yang tidak menyenangkan dari proses kehidupan. Kematian memiliki sifat abstrak, tidak dapat dikontrol, tidak memiliki wujud, serta tidak dapat dipahami (Royal \& Fereshte, 2011). Sifat kematian yang tidak dapat diprediksi mampu memicu rasa prihatin, rasa takut, dan rasa cemas (Yalom, 1980).

Kecemasan menghadapi kematian merupakan fenomena umum yang terjadi pada manusia di segala rentang usia dan dapat dipandang sebagai motivasi dasar dari perilaku manusia (Cicirelli, 2002). Kecemasan menghadapi kematian sulit untuk didefinisikan karena memang pada kenyataannya, pembahasan mengenai konsep kematian sendiri membuat manusia merasa tidak nyaman (Cavanaugh \& Blanchard-Field, 2011).

Di beberapa tempat di Indonesia, tingkat kecemasan menghadapi kematian pada lansia masih tergolong tinggi. Hasil penelitian yang dilakukan oleh Pamungkas, Wiyanti, dan Agustin (2013) mengungkap bahwa tingkat kecemasan menghadapi kematian pada lansia di daerah Jebres, Surakarta masih cenderung tinggi. Selain di Surakarta, hasil penelitian yang dilakukan oleh Setyawan (2015) juga mengungkap tingkat kecemasan menghadapi kematian yang tinggi pada lansia yang tinggal di daerah Ngablak, Magelang.

Faktor yang memengaruhi kecemasan menghadapi kematian telah banyak diteliti di berbagai negara. Faktor-faktor tersebut antara lain self-efficacy, religiusitas, selfesteem, dan kearifan. Menurut penelitian Fry (2003), self-efficacy merupakan prediktor penting dalam menurunkan kecemasan menghadapi kematian pada lansia. Sedangkan menurut penelitian Krause dan Hayward (2014), religiusitas 
mampu menurunkan kecemasan menghadapi kematian pada lansia karena individu yang religius percaya bahwa dirinya akan mendapat pengampunan dari Tuhan. Penelitian yang dilakukan oleh Cicirelli (2002) juga menunjukkan bahwa lansia dengan self-esteem yang tinggi tidak merasakan cemas terhadap kematian. Kearifan, menurut hasil penelitian yang dilakukan oleh Ardelt (2007), mampu berperan dalam menurunkan kecemasan menghadapi kematian pada lansia. Usia lanjut banyak dikaitkan dengan kearifan, seperti banyak pepatah yang mengatakan semakin tua semakin arif. Individu yang arif biasanya memiliki beberapa karakteristik positif, seperti kepribadian yang matang dan terintegrasi, keterampilan judgement yang superior, dan kemampuan untuk menyesuaikan diri dengan perubahan dalam hidup (Ardelt, 2004). Perubahan-perubahan dalam hidup yang dimaksud termasuk saat menghadapi kematian (Wicaksono \& Meiyanto, 2003).

Usia lanjut banyak dikaitkan dengan kearifan, seperti banyak pepatah yang mengatakan semakin tua semakin arif. Kearifan dapat diartikan sebagai kombinasi dari faktor kognitif, afektif, dan reflektif (Ardelt, 2003). Kearifan atau kebijaksanaan adalah suatu proses di mana individu memiliki kemasakan dalam mengintegrasikan ketiga faktor diatas (Wicaksono \& Meiyanto, 2003). Individu yang arif biasanya memiliki beberapa karakteristik positif, seperti kepribadian yang matang dan terintegrasi, keterampilan judgement yang superior, dan kemampuan untuk menyesuaikan diri dengan perubahan dalam hidup (Ardelt M.,2004). Perubahan-perubahan dalam hidup yang dimaksud termasuk saat menghadapi kematian (Wicaksono \& Meiyanto, 2003).
Individu yang arif mampu memahami perubahan-perubahan yang dialami dalam hidupnya serta mampu melihat fenomena dalam hidupnya dari berbagai persepektif (Ardelt, 2007). Individu yang arif juga mampu menerima dan menemukan arti dari hal-hal yang dialaminya termasuk penderitaan. Penerimaan yang dilakukan oleh individu yang arif bukan disebabkan oleh keputusasaan, akan tetapi karena individu merasa bahwa hidup yang dialami seperti air yang mengalir (Randall \& Kenyon, 2001). Penerimaan, pemahaman, dan kemampuan individu dalam menemukan arti fenomena-fenomena dalam hidupnya membuat individu paham bahwa kematian merupakan salah satu bagian dari kehidupan sehingga individu tersebut tidak merasa cemas dalam menghadapi kematiannya (Ardelt, 2007).

Topik mengenai kecemasan menghadapi kematian pada lansia sudah banyak dibahas di Indonesia, akan tetapi belum ada penelitian yang membahas mengenai peran kearifan terhadap kecemasan menghadapi kematian pada lansia. Berdasarkan pemaparan di atas, penelitian ini bertujuan untuk mengetahui peran kearifan terhadap kecemasan menghadapi kematian pada lansia. Peneliti memiliki hipotesis bahwa kearifan mampu memprediksi kecemasan menghadapi kematian pada lansia dengan arah yang berkebalikan, sehingga dapat dikatakan apabila kearifan tinggi, maka kecemasan menghadapi kematian akan menjadi rendah.

\section{Metode}

Variabel prediktor yang digunakan dalam penelitian ini adalah kearifan, sedangkan variabel kriteria yang digunakan adalah kecemasan menghadapi kematian. Subjek penelitian yang digunakan adalah lansia dengan kisaran usia 60 hingga 85 tahun, 
tidak mengalami sakit fisik yang serius, tinggal di rumah. Jumlah subjek yang didapat sebanyak 130 orang. Subjek penelitian mayoritas berdomisili di Yogyakarta. Pengumpulan data penelitian dilakukan secara kolektif dan individual.

Pengumpulan data penelitian dilakukan secara kolektif dan individual. Pengumpulan data kolektif dilakukan dengan mendatangi kelompok senam lansia di Kampung Kauman Yogyakarta. Pengumpulan data individual dilakukan dengan metode snowball sampling, dimana subjek akan mengarahkan peneliti pada subjek lainnya. Metode ini memungkinkan peneliti untuk mendapatkan subjek yang sesuai dengan kriteria subjek penelitian yang lebih banyak.

Kecemasan menghadapi kematian pada penelitian diukur menggunakan skala Death Anxiety Scale milik Templer yang telah dimodifikasi oleh McMordie (1979). Death Anxiety Scale asli terdiri dari 15 aitem yang berisi berbagai pernyataanpernyataan yang berkaitan dengan kematian, akan tetapi pada penelitian ini, Death Anxiety Scale yang digunakan terdiri dari 13 aitem.

Variabel kearifan diukur menggunakan adaptasi dari Three-Dimensional Wisdom Scale dari Ardelt (2003). Skala ThreeDimensional Wisdom asli terdiri dari 39 aitem dan dibagi menjadi dua bagian, akan tetapi pada penelitian ini, skala ThreeDimensional Wisdom yang digunakan terdiri dari 37 aitem.

Metode try-out terpakai digunakan dalam penelitian ini, sehingga analisis uji hipotesis dilakukan pada 130 subjek yang telah didapat melalui prosedur uji coba. Hal ini dilakukan karena subjek penelitian dengan rentang usia lansia sulit untuk didapatkan. Keputusan dari hasil uji coba tersebut menyebabkan jumlah aitem dalam penelitian berbeda dengan skala aslinya.
Untuk mengetahui pengaruh variabel prediktor terhadap variabel kriteria, hipotesis dalam penelitian ini diuji dengan analisis regresi linear sederhana menggunakan program SPSS 20 for Windows. Peneliti juga melakukan analisis tambahan melalui uji statistik dengan teknik one-way between group analysis of variance pada kecemasan menghadapi kematian dan data demografis usia, jenis kelamin, agama, tingkat pendidikan, status perkawinan, dan jumlah anak. Uji statistik ANOVA pada penelitian ini dilakukan untuk melihat variabilitas dari distribusi skor kecemasan menghadapi kematian dan mengurai sejauh variabilitas tersebut terkait dengan berbagai faktor dari proses pengukuran.

\section{H a s i 1}

Peneliti mengajukan hipotesis bahwa kebijaksanaan memiliki pengaruh negatif terhadap kecemasan menghadapi kematian. Analisis regresi linear sederhana dilakukan pada data yang diperoleh dari 130 orang lansia yang mayoritas berdomisili di Yogyakarta.

Berdasarkan analisis data penelitian, rata-rata empirik variabel kecemasan menghadapi kematian lebih rendah $(M=34)$ daripada rata-rata hipotetiknya $(M=36)$. Hasil kategorisasi variabel kecemasan menghadapi kematian menunjukkan bahwa mayoritas subjek berada pada kategori sedang (42.3\%) dan kategori rendah $(32.3 \%)$. Skor rata rata empirik variabel kearifan lebih tinggi $(M=113)$ daripada rata-rata hipotetiknya $(M=105)$. Hasil dari kategorisasi variabel kearifan menunjukkan bahwa lansia mayoritas masuk ke dalam kategori sedang (54.6\%) dan mengarah kepada kategori tinggi (37.7\%). 
Sebelum melakukan pengujian hipotesis, peneliti melakukan uji asumsi terlebih dahulu. Uji asumsi yang dilakukan dalam penelitian ini adalah uji normalitas dan uji linearitas. Pengujian normalitas residual dilakukan dengan menggunakan uji Kolmogorov-Smirnov (KSZ) melalui bantuan SPSS. Berdasarkan hasil uji normalitas residual, diketahui bahwa nilai KSZ sebesar 0.64 dengan skor $p$ sebesar 0.82 ( $p>0.05)$. Hasil ini menunjukkan bahwa data terdistribusi normal.

Skor linearity sebesar 0.01 yang dihasilkan melalui uji linearitas menunjukkan bahwa hubungan linear antara variabel dependen dengan variabel independen yang cukup kuat. Hasil ini didukung pula oleh skor deviation from linearity sebesar 0.14 ( $p>0.05$ ) yang berarti bahwa penyimpangan hubungan variabel independen dengan variabel dependen dari linearitas tidak terjadi.

Setelah melakukan uji asumsi, uji hipotesis dilakukan. Uji hipotesis dilakukan menggunakan teknik analisis regresi sederhana. Persamaan regresi yang signifikan ditemukan $(F(1.128)=21.37, p<$ $0.01)$, dengan skor $R^{2}$ sebesar 0.143 . Hasil ini menunjukkan adanya $p$ yang signifikan. Varibel kearifan memberikan sumbangan sebesar $14.3 \%$ terhadap kecemasan menghadapi kematian, dan sisanya sebesar $85.7 \%$ merupakan sumbangan dari faktorfaktor lainnya.

Hasil analisis tambahan menggunakan uji statistik One Way ANOVA tidak menemukan adanya perbedaan skor kecemasan menghadapi kematian pada lansia yang dikelompokkan berdasarkan usia, jenis kelamin, agama, jumlah anak, dan status pernikahan. Perbedaan yang signifikan ditemukan pada skor kecemasan menghadapi kematian lansia berdasarkan tingkat pendidikan. Rata-rata skor kecemasan menghadapi kematian tertinggi ada pada kelompok subjek yang tidak mengenyam pendidikan, sedangkan ratarata skor kecemasan menghadapi kematian terendah ada pada kelompok subjek yang mengenyam pendidikan hingga perguruan tinggi.

\section{Diskusi}

Kematian merupakan peristiwa yang tidak dapat terelakkan. Kematian sendiri masih menjadi suatu tanda tanya besar karena kematian bersifat irreversible. Kematian yang tidak dapat diketahui secara pasti dapat memicu seseorang menjadi merasa cemas.

Individu juga dapat merasa cemas menghadapi kematian karena ia belum siap dan masih merasa ada yang kurang dengan hidup yang telah dilaluinya. Hal ini seperti yang dicetuskan oleh Tomer dan Eliason (1996) dalam Model of Death Anxiety. Dalam model ini, seseorang merasa cemas atau tidak dalam menghadapi kematian tergantung pada bagaimana individu tersebut mengevaluasi hidupnya dan ada atau tidak penyesalan yang dirasakan dalam hidupnya. Tidak ada penyesalan dalam hidup merupakan salah satu aspek dari konsep kearifan yang dicetuskan oleh Ardelt (2003).

Hasil penelitian ini menunjukkan adanya peran yang signifikan kearifan terhadap kecemasan menghadapi kematian. Dengan demikian hipotesis yang diajukan, diterima. Adanya peran variabel kearifan terhadap kecemasan menghadapi kematian sesuai dengan hasil dari penelitian Ardelt (2007).

Ardelt (2007) berpendapat bahwa kearifan dapat membuat lansia mengerti makna dari hidup, menerima perubahanperubahan dalam hidup serta melihat segala peristiwa dalam hidup dari berbagai peristiwa mampu membuat lansia 
menerima keterbatasan yang dimiliki oleh manusia, termasuk datangnya kematian sebagai salah satu fase kehidupan. Penerimaan yang menjadi karkateristik utama dari kearifan juga membuat lansia mengevaluasi positif kehidupannya sehingga lansia tidak memiliki penyesalan apapun dalam hidupnya (Randall \& Kenyon, 2001). Tidak adanya penyesalan dalam hidup menjadikan lansia tidak cemas dan siap dalam menghadapi kematian, baik kematian dirinya maupun orang terdekatnya (Azeem \& Naz, 2015).

Hasil dari uji statistik One Way ANOVA menemukan adanya perbedaan skor kecemasan menghadapi kematian pada lansia yang dikelompokkan berdasarkan tingkat pendidikan. Rata-rata skor kecemasan menghadapi kematian tertinggi ada pada kelompok subjek yang tidak mengenyam pendidikan, sedangkan ratarata skor kecemasan menghadapi kematian terendah ada pada kelompok subjek yang mengenyam pendidikan hingga perguruan tinggi. Hasil tersebut sesuai dengan penelitian yang dilakukan oleh Swenson (1961), yang menemukan adanya pengaruh tingkat pendidikan terhadap kecemasan menghadapi lansia. Menurut Swenson, rendahnya kecemasan menghadapi kematian pada lansia yang memiliki tingkat pendidikan tinggi disebabkan oleh sulitnya konsep kematian untuk dipahami sehingga hanya orang-orang dengan tingkat pengetahuan yang tinggi.

Penelitian ini juga mengungkap bahwa lansia memiliki tingkat kecemasan menghadapi kematian cenderung rendah. Hasil ini menandakan lansia cenderung tidak merasa cemas ketika bersinggungan dengan kematian, baik kematian orang lain maupun kematian diri sendiri. Rendahnya kecemasan menghadapi kematian juga menandakan bahwa lansia sudah memiliki penyesuaian diri yang cukup dalam menghadapi kematian, sehingga sudah melakukan tugas perkembangan dengan baik.

Individu yang tidak merasa cemas terhadap kematian, menurut Azeem dan Naz (2015) adalah individu yang mengevaluasi hidupnya secara positif, sehingga dirinya tidak merasa terbebani dengan halhal yang telah terjadi pada dirinya. Kemampuan individu memahami perubahan yang terjadi dalam hidupnya, mampu melihat sesuatu dari berbagai sudut pandang, dan mampu menemukan arti segala peristiwa yang dilalui dalam hidupnya merupakan karakteristik positif dari individu yang arif (Ardelt, 2004).

Hasil penelitian ini menemukan bahwa mayoritas lansia memiliki kearifan yang cenderung tinggi, sehingga dapat diartikan bahwa lansia sudah cukup mampu memahami dan menerima perubahan yang terjadi dalam hidupnya serta cukup mampu melihat segala peristiwa dari berbagai sudut pandang.

Kearifan memiliki karakteristik utama berupa penerimaan (Randall \& Kenyon, 2001). Penerimaan yang dilakukan berbeda dengan putus asa, karena penerimaan yang dilakukan oleh individu yang arif merupakan wujud berserah diri pada perubahan-perubahan yang terjadi dalam hidupnya, termasuk dalam menghadapi kematian (Ardelt \& Edwards, 2015). Kearifan juga mampu membuat lansia melihat segala fenomena yang terjadi pada hidupnya dari berbagai sudut pandang (Ardelt, 2003).

Dengan demikian, lansia yang arif akan pasrah dan tanpa putus asa menerima kondisi dirinya yang terus menurun hingga datangnya kematian. Lansia yang arif juga mampu memandang kematian dari berbagai sudut pandang sehingga mampu memandang kematian secara positif. Penerimaan serta kemampuan 
untuk melihat kematian dari berbagai sudut pandang inilah yang mampu menurunkan kecemasan menghadapi kematian pada lansia.

Dalam penelitian ini, subjek penelitian sering kali merasa kesulitan dalam mengerjakan skala, terutama subjek-subjek yang berusia di atas 70 tahun dan tidak mengenyam pendidikan dasar. Subjek juga merasa kesulitan memahami apabila dihadapkan pada skala dengan aitem yang memuat kalimat-kalimat negasi atau aitem unfavorable.

\section{Kesimpulan}

Berdasarkan penelitian yang telah dilakukan dapat disimpulkan bahwa hipotesis diterima. Tinggi rendahnya kearifan pada lansia dapat digunakan untuk memprediksi tinggi rendahnya kecemasan menghadapi kematian. Kearifan juga memberikan sumbangan efektif sebesar $14.3 \%$ terhadap kecemasan menghadapi kematian. Di samping itu, penelitian juga menyimpulkan adanya perbedaan kecemasan terhadap kematian pada lansia berdasarkan tingkat pendidikan. Lansia yang menempuh pendidikan hingga perguruan tinggi memiliki tingkat kecemasan menghadapi kematian yang paling rendah.

\section{Saran}

Hasil penelitian diharapkan dapat menjadi bahan pertimbangan bagi institusi yang bergerak di bidang sosial dalam menyusun program-program yang berkaitan dengan lansia. Hasil penelitian ini menunjukkan adanya peran kearifan dalam memprediksi kecemasan menghadapi kematian pada lansia, oleh sebab itu, institusi sosial disarankan agar membuat programprogram yang mampu mempertahankan atau meningkatkan kearifan pada lansia.
Program tersebut dapat berbentuk seperti intervensi atau pelatihan serta penyuluhan yang mengangkat tema penerimaan kondisi lansia yang terus menurun, sehingga lansia mampu menerima kondisinya dan tidak merasakan cemas dalam menghadapi kematian.

Bagi peneliti selanjutnya disarankan untuk menggunakan alat ukur yang lebih mudah dipahami dan dimengerti oleh subjek serta tidak memiliki butir aitem yang terlalu banyak. Alat ukur yang digunakan sebaiknya tidak memuat aitem unfavorable, sebab aitem tersebut kerap kali membuat subjek bingung.

\section{Kepustakaan}

Ardelt, M. (2003). Empirical assessment of a three dimensional wisdom scale. Research on Aging, 25(3), 275-324. doi: 10.1177/0164027503025003004

Ardelt, M. (2004). Wisdom as expert knowledge system: A critical review of a contemporary operationalization of an ancient concept. Human Development, 47, 257-285. doi: 10.1159/ 000079154

Ardelt, M. (2007). Wisdom, religiosity, purpose in life, and death attitudes of aging adults. In A. Tomer, G. T. Eliason, \& P. T. Wong, Existensial and spiritual issues in death attitude (pp. 139158). New Jersey: Lawrence Erlbau Associates.

Ardelt, M., \& Edwards, C. A. (2015). Wisdom at the end of life: An analysis of mediating and moderating relations between wisdom and subjective wellbeing. J Gerontol B Psychol Sci Soc Sci, 00(00), 1 - 12. doi: 10.1093/geronb/ gbv051

Azeem, F., \& Naz, M. A. (2015). Resilience, death anxiety, and depression among 
institutionalized and noninsititutionalized elderly. Pakistan Journal of Psychological Research, 30(1), 111-130.

Cao, J., \& Rammohan, A. (2016). Social capital and healthy ageing in Indonesia. BMC Public Health, 631-645.

Cavanaugh, J. C., \& Blanchard-Field, F. (2011). Adult development and aging. Belmont: Thompson Learning.

Cicirelli, V. G. (2002). Fear of death in older adults: Prediction from terror management theory. Journal of Gerontology, 57(4), 358-366. doi: 10.1093/ geronb/57.4.P358

Fry, P. (2003). Percieved self efficacy domains as predictors of fear of the unknown and fear of dying. Psychology and Aging, 18(3), 474-486. doi: 10.1037/ 0882-7974.18.3.474

Hurlock, B. E. (1980). Psikologi perkembangan suatu pendekatan sepanjang rentang kehidupan. Jakarta: Erlangga.

Kompas. (2016, Oktober 24). Sel punca prospektif untuk anti penuaan. Kompas Rubrik Iptek Lingkungan dan Kesehatan. Jakarta: Gramedia Printing.

Krause, N., \& Hayward, D. (2014). Religious involvement and death anxiety. Omega, 69(1), 59-87. doi: 10. 2190/OM.69.1.d

Liffiton, J. A., Horton, S., Baker, J., \& Weir, P. L. (2012). Successful aging: How does physical activity influence engagement with life? European Review of Aging and Physical Activity, 103-108. doi: 10.1007/s11556-012-0098-0

McMordie, W. R. (1979). Improving measurement of death anxiety. Psychological Reports, 44(3), 975-980. doi: 10.2466/pr0.1979.44.3.975
Pamungkas, A., Wiyanti, S., \& Agustin, R. W. (2013). Hubungan antara religiusitas dan dukungan sosial dengan kecemasan menghadapi tutup usia pada lanjut usia kelurahan Jebres Surakarta. Jurnal Ilmiah Psikologi Candrajiza, 2(1), 1-10.

Randall, W. L., \& Kenyon, G. M. (2001). Ordinary wisdom: Biographical aging and the journey of life. Westport: Praeger.

Royal, K., \& Fereshte, E. (2011). Psychometric properties of the death anxiety scale among terminally ill patients. Journal of Psychosocial Oncology, 29(4), 359-371. doi: 10.1080/ 07347332.2011.582639

Setyawan, M. F. (2015). Hubungan spiritualitas dengan tingkat kecemasan menghadapi kematian pada lansia umur di atas 60 tahun di dusun Tanggulangin. Yogyakarta: Unpublish Thesis, STIKES Aisyiyah.

Stephoe, A., Deaton, A., \& Stone, A. A. (2015). Psychological wellbeing, health, and ageing. Lancet, 640-648. doi: 10. 1016/S0140-6736(13)61489-0

Swenson, W. M. (1961). Attitude toward death in aged population. Journal of Gerontology, 16, 49-52.

Tomer, A., \& Eliason, G. (1996). Toward a comprehensive model of death anxiety. Death Studies, 20(4), 346-365. doi: 10. 1080/07481189608252787

Wicaksono, W., \& Meiyanto, S. (2003). Ketakutan terhadap kematian ditinjau dari kebijaksanaan dan orientasi religius pada periode remaja akhir yang berstatus mahasiswa. Jurnal Psikologi, 30(1), 57-65.

Yalom, I. (1980). Existential psychoteraphy. New York: Basic Books. 